\title{
Meiosis and spermatogenesis in bulls heterozygous for a presumptive $1 / 29$ Robertsonian translocation
}

\author{
D. N. Logue* and M. J. A. Harvey \\ Department of Veterinary Reproduction, University of Glasgow Veterinary School, \\ Bearsden, Glasgow G61 1QH, U.K.
}

\begin{abstract}
Summary. Bulls heterozygous for the 1/29 Robertsonian translocation showed normal mating behaviour, semen quality and spermatogenesis. The karyotypes of 90 offspring of one heterozygous bull were consistent with a normal 1:1 segregation of the translocation. There was no difference in overall chiasma frequency at diakinesis between heterozygous and normal bulls, and while a trivalent was noted at diakinesis the chiasma position within the No. 1 arm of the trivalent did not appear to be altered when compared with that found in the normal No. 1 bivalent. An increased frequency of aneuploid secondary spermatocytes at the second meiotic division (M II) was found in the heterozygous bulls, the rate of non-disjunction based on the proportion of hypermodal cells being raised from $2 \cdot 8 \%$ in the normal to $6.4 \%$ in the heterozygous animals.
\end{abstract}

\section{Introduction}

The Robertsonian translocation has been a frequently described chromosome anomaly in ruminants (Bruère, 1974). The most common is the ' $1 / 29$ ' translocation first reported for the Swedish Red and White breed by Gustavsson \& Rockborn (1964). A very similar translocation has since been found in most cattle-rearing countries, although it is at present impossible to state if the affected cattle are all related by descent (Gustavsson, 1974). Despite this apparently widespread distribution, only Gustavsson (1969) and Refsdal (1976) have presented statistical evidence from breeding data that in the heterozygous state the $1 / 29$ translocation causes a reduction of reproductive efficiency. Gustavsson (1969) considered that this was due to the failure of the translocation chromosome to disjoin from one of its two acrocentric partners during parental meiosis (non-disjunction). He postulated that these unbalanced gametes formed unbalanced embryos which subsequently died during early development in utero. Gustavsson (1969) studied secondary spermatocytes at M II for evidence of increased non-disjunction in heterozygous bulls but the 151 (from heterozygotes) and 38 (from normal bulls) cells at $\mathrm{M}$ II were insufficient to demonstrate any significant difference from the control rate.

In 1971 Harvey found a presumptive $1 / 29$ translocation in a Charolais bull and the present report is of our subsequent investigations.

\section{Materials and Methods}

Blood samples for chromosome studies were obtained from 90 offspring of the heterozygous bull reported by Harvey (1971) and cultured (Basrur \& Gilman, 1964). Six of the offspring, each with different dams ( 3 heterozygous males, 2 normal males and 1 normal female) were purchased for more extensive study. Confirmation of their chromosome complements was sought by culturing fibroblasts (Basrur, Basrur \& Gilman, 1963).

The chromosomes of 10 translocation-bearing cells stained with $2 \%$ aceto-orcein were measured and an idiogram was constructed. Subsequently, more precise chromosome identification was attempted by using the G- and C-band staining methods of Seabright (1971) and Sumner (1972).

Semen was collected from each of the 5 bulls at least once a month, and 50-328 ejaculates/bull were examined as described by Hignett (1957). Testicular material for spermatogenic and meiotic

\footnotetext{
* Present address: M.L.C. Pig Breeding Centre, Thorpe Willoughby, Selby, Yorkshire YO8 9HL, U.K.
} 
studies was obtained from the 5 bulls by biopsy, castration or at slaughter, while some further control material was gathered from apparently normal testes of 48 bulls slaughtered at local abattoirs. From the histological preparations, Leydig cell volume and relative tubule length were computed for each of the 5 bulls (Lennox, Ahmad \& Mack, 1970; Ahmad, Dykes, Ferguson-Smith, Lennox \& Mack, 1971). Meiotic preparations of cells from all the bulls were made by a modification of the method of Ferguson-Smith (1964).

The various stages of meiosis were identified and studied. At diakinesis, chiasma counts of suitable cells from normal and heterozygous bulls were made and compared and the chiasma distributions on the largest bivalent, the presumptive No. 1, and those on the No. 1 arm of the heterozygous trivalent were also compared. Chromosome counts of suitably spread M II cells were made, although some difficulty was experienced because of the tendency of the chromatids of some chromosomes to separate from one another at the centromere. This happened frequently to the large sub-metacentric translocation chromosome, less frequently to the acrocentric autosomes, and rarely to the sex chromosomes. An attempt to circumvent this difficulty was made by counting each chromatid of the translocation metacentric chromosome as one, whether they were separate or not. Therefore, in a balanced translocation-carrying cell there was a count of ' 30 ', exactly as in a normal cell. Subsequently, the cell was re-examined to determine whether it possessed a translocation chromosome; if there was any doubt the cell was considered as normal.

\section{Results}

All the offspring of the affected bull were phenotypically normal and chromosomally balanced: 24 of the animals had a $59 \mathrm{XXt}(1,29)$ karyotype, 17 had a $59 \mathrm{XYt}(1,29), 23$ were $60 \mathrm{XX}$ and 26 were $60 \mathrm{XY}$.

The idiogram measurements indicated that the large translocation chromosome was most probably composed of chromosomes 1 and 29 . G-banding confirmed the presence of the No. 1 chromosome which was easily identified by its two prominent subdivisible dark bands one-third and twothirds down its length. Recognition of the short-arm chromosome was much more difficult because chromosomes 27 and 29 have a similar G-band pattern, but it was thought to be chromosome 29 from its consistently small size (Pl. 1, Fig. 1). The centromeric region of the translocation chromosome in the G-and C-banded preparations (Pl. 2, Fig. 3), showed that approximately half of the total amount of $\mathrm{C}$-band heterochromatin found in the normal 1 and 29 chromosomes had been lost in the translocation metacentric.

The 5 bulls all showed normal service behaviour. Semen quality and spermatogenesis were qualitatively normal and Leydig cell volumes and relative total tubule lengths were similar (Table 1).

Table 1. Relative tubule length and Leydig cell volumes in the left (L) and right (R) testes of normal and 1/29 heterozygous bulls

\begin{tabular}{|c|c|c|c|c|c|}
\hline Bull & Karyotype & Testis & $\begin{array}{c}\text { Relative } \\
\text { tubule } \\
\text { length }(\mathrm{m})\end{array}$ & $\begin{array}{l}\text { Leydig } \\
\text { cell } \\
\text { vol. (ml) }\end{array}$ & $\begin{array}{c}\text { Volume } \\
\text { of testis } \\
\text { (ml) }\end{array}$ \\
\hline 52082 & $60 X Y$ & $\begin{array}{l}\mathbf{L} \\
\mathbf{R}\end{array}$ & $\begin{array}{l}2806 \\
2703\end{array}$ & $\begin{array}{l}12 \\
10\end{array}$ & $\begin{array}{l}264 \\
268\end{array}$ \\
\hline 51728 & $60 X Y$ & $\begin{array}{l}\mathbf{L} \\
\mathbf{R}\end{array}$ & $\begin{array}{l}3060 \pm 240^{*} \\
3407\end{array}$ & $\begin{array}{l}16 \\
18\end{array}$ & $\begin{array}{l}272 \\
301\end{array}$ \\
\hline 47953 & $59 \times Y, t(1,29)$ & $\begin{array}{l}\mathbf{L} \\
\mathbf{R}\end{array}$ & $\begin{array}{l}3522 \\
2805 \pm 320^{*}\end{array}$ & $\begin{array}{l}17 \\
24\end{array}$ & $\begin{array}{l}282 \\
301\end{array}$ \\
\hline 54638 & $59 \mathrm{XY}, \mathrm{t}(1,29)$ & $\begin{array}{l}\mathbf{L} \\
\mathbf{R}\end{array}$ & $\begin{array}{l}3316 \\
3655\end{array}$ & $\begin{array}{l}16 \\
20\end{array}$ & $\begin{array}{l}262 \\
272\end{array}$ \\
\hline 57074 & $59 X Y, t(1,29)$ & $\begin{array}{l}\mathbf{L} \\
\mathbf{R}\end{array}$ & $\begin{array}{l}2965 \\
3112\end{array}$ & $\begin{array}{l}13 \\
18\end{array}$ & $\begin{array}{l}194 \\
185\end{array}$ \\
\hline
\end{tabular}

* Mean \pm s.d. of 4 estimates. 
The translocation chromosome and its homologues could occasionally be identified at pachytene (Pl. 1, Fig. 2), but pairing was never obviously disturbed. It was not until diplotene and diakinesis that an asymmetric trivalent could be easily identified (Pl. 2, Fig. 4). The mean chiasma count of 150 cells studied from the three heterozygous bulls was $47 \cdot 8 \pm 4 \cdot 2$ compared with $49 \cdot 5 \pm 4 \cdot 1$ in 325 cells from the 2 normal half-brothers and 31 'control' bulls (Pl. 2, Fig. 5). There was no evidence of synaptic irregularities in any bull. The distribution of the number and position of the chiasmata between the long (No. 1) arm of the translocation chromosome and the No. 1 homologue (in trivalents), and in the No. 1 bivalents of the normal bulls corresponded very closely (Table 2).

Table 2. Comparison of the numbers and distribution of chiasmata in trivalents at diakinesis from $1 / 29$ heterozygous bulls with those found in the presumptive No. 1 bivalent found in chromosomally normal bulls

\begin{tabular}{|c|c|c|c|c|c|}
\hline \multicolumn{5}{|c|}{ Trivalents $(1 / 29,1$ and 29$)$} & \multirow{3}{*}{$\frac{\begin{array}{c}\text { Bivalents } \\
\text { (presumptive 1) }\end{array}}{\begin{array}{c}\text { No. of } \\
\text { observations }\end{array}}$} \\
\hline \multicolumn{2}{|c|}{$\begin{array}{l}\text { No. of } \\
\text { chiasmata }\end{array}$} & \multicolumn{2}{|c|}{$\begin{array}{c}\text { Position of chiasmata* } \\
\text { in component } \\
\text { 'half-trivalents' } \\
\end{array}$} & \multirow[b]{2}{*}{$\begin{array}{c}\text { No. of } \\
\text { observations }\end{array}$} & \\
\hline $\begin{array}{l}\text { Long } \\
\text { arm (1) }\end{array}$ & $\begin{array}{c}\text { Short } \\
\operatorname{arm}(29)\end{array}$ & (1) & (29) & & \\
\hline 1 & 1 & $T$ & $\mathrm{~T}$ & 1 & 0 \\
\hline 1 & 1 & $\mathbf{M}$ & $\mathbf{X}$ & 8 & 5 \\
\hline 2 & 1 & T P & $\mathbf{x}$ & 10 & 8 \\
\hline 2 & 1 & T M & $\mathrm{X}$ & $48\}$ & \\
\hline 2 & 2 & T M & $\mathbf{T} \mathbf{P}$ & $2\}$ & 31 \\
\hline 2 & 1 & M M & $\mathrm{X}$ & $20\}$. & \\
\hline 2 & 2 & M M & $\mathbf{T} \mathbf{P}$ & $2\}$ & 24 \\
\hline 3 & 1 & T M P & $\mathbf{X}$ & 9 & 8 \\
\hline 4 & 1 & T M M P & $\mathbf{x}$ & $5\}_{6}$ & 4 \\
\hline 2 & 2 & $\mathrm{~T} \mathbf{M} \mathbf{M} \mathbf{P}$ & $\mathbf{T} \mathbf{P}$ & $1\}^{0}$ & 4 \\
\hline
\end{tabular}

\footnotetext{
* Positions of chiasmata were recorded as $\mathrm{T}=$ terminal, $\mathrm{M}=$ median, $\mathrm{P}=$ proxima and $\mathrm{X}=$ undefined.

† Of bivalents with chiasmata in the positions shown in column 3 .
}

A total of 388 cells from the heterozygous bulls and 601 from the normal animals was counted at M II (Pl. 2, Figs, 6, 7 and 8). The results are shown in Table 3 . There was a highly significant difference between the number of presumptively intact cells that included the translocation and the number which lacked one, presumably due to misidentification of separated chromatids. Again the distribution of counts was highly skewed and there was a great excess of hypomodal cells $(n-1)$ over hypermodal $(n+1)$ cells (Table 4). This skew was considered to be due to loss of chromosomes from some cells because of technical deficiencies. Together these two observations created difficulties in estimating the rate of non-disjunction at meiosis. Both Ford \& Evans(1973) and Cattanach \& Moseley (1973) discussed this problem, and they considered that the most accurate estimation was computed by doubling the frequency of hypermodal cells $(n+1)$ and expressing this as a percentage of the total number of cells within 1 chromosome count of the modal number (n) (Table 4). Expressed mathematically this is:

$$
\mathbf{R}_{1}=\frac{2 \times \Sigma(\mathrm{n}+1)}{\Sigma(\mathrm{n}-1)+\Sigma \mathrm{n}+\Sigma(\mathrm{n}+1)} \times 100 \%
$$

This gave a value of $2 \cdot 8 \%$ for normal animals and $6.4 \%$ for heterozygotes. When the theoretically more correct formula (Ford \& Evans 1973),

$$
\mathbf{R}_{2}=\frac{\Sigma(\mathrm{n}-1)+\Sigma(\mathrm{n}+1)}{\Sigma(\mathrm{n}-1)+\Sigma \mathrm{n}+\Sigma(\mathrm{n}+1)} \times 100 \%
$$

is used, the corresponding frequencies were $10 \cdot 6$ and $16 \cdot 1$. 
Table 3. Chromosome counts of cells at M II obtained from $1 / 29$ heterozygous and normal bulls

\begin{tabular}{|c|c|c|c|c|c|c|c|c|}
\hline & \multicolumn{8}{|c|}{ No. of chromosomes } \\
\hline & \multicolumn{4}{|c|}{ Translocation identified } & \multicolumn{4}{|c|}{ No translocation } \\
\hline & 27 & 28 & 29 & 30 & 28 & 29 & 30 & 31 \\
\hline Normal bulls & & & & & 35 & 52 & 506 & 8 \\
\hline Heterozygous bulls & 8 & 23 & 128 & 7 & 7 & 25 & 185 & 5 \\
\hline
\end{tabular}

Table 4. Corrected data for chromosome counts from Table 3 based on the relationship to the modal number (n) to facilitate computation of non-disjunction rates

\begin{tabular}{lccr}
\hline & \multicolumn{3}{c}{ Variation from modal no. } \\
\cline { 2 - 4 } & $\mathrm{n}-1$ & $\mathrm{n}$ & $\mathrm{n}+1$ \\
\hline Normal bulls & 52 & 506 & 8 \\
Heterozygous bulls & 48 & 313 & 12 \\
\hline
\end{tabular}

\section{Discussion}

In this study the chromosome survey of offspring of a bull heterozygous for the $1 / 29$ translocation confirmed previous work: only normal and balanced animals were found and these occurred in a 1:1 ratio unaffected by sex (Gustavsson, 1969). A similar conclusion has been reached for several other Robertsonian translocations in cattle (Pollock \& Bowman, 1974; Logue, 1975).

Although the translocation chromosome could not be unequivocally identified as a $1 / 29$ translocation, the measurements, similarity of the banding pattern and the presence of a trivalent at diakinesis, gave a reasonable basis for the assumption. The 1/29 translocation, unlike all the other Robertsonian translocations so far studied by banding methods (Eldridge, 1974; Pollock \& Bowman, 1974; Logue, 1975), has apparently lost a considerable portion of C-band heterochromatin (Popescu, 1973). A possible mode of formation of these variations in the C-band content of Robertsonian translocations has been suggested by Ferguson-Smith (1971).

\section{EXPLANATION OF PLATES}

\section{PLATE 1}

Fig. 1. A G-banded karyotype of a $1 / 29$ heterozygous bull, $59 \mathrm{XY}, \mathrm{t}(1,29) . \times 2000$.

Fig. 2. Primary spermatocyte at pachytene (M I, 29XY,III(1,29)) from a $1 / 29$ heterozygous bull. The arrow indicates the presumptive trivalent. $\times 2000$.

\section{PLATE 2}

Fig. 3. C-banded mitotic chromosomes from a $1 / 29$ heterozygous bull showing the large submetacentric translocation chromosome and the presumptive chromosomes 1 and $29 . \times 2300$.

Fig. 4. Three $1 / 29$ trivalents at diakinesis. $\times 2000$.

Fig. 5. Primary spermatocyte (M I, 30XY) from a normal bull. $\times 2000$.

Fig. 6. Secondary spermatocyte at metaphase (M II, 30X) from a normal bull. The X chromosome is indicated. $\times 2300$.

Fig. 7. Unbalanced secondary spermatocyte at metaphase (M II, 30Y,t(1,29)+ ?) from a $1 / 29$ heterozygous bull. The $Y$ and translocation chromosome $(t)$ are indicated. $\times 2300$.

Fig. 8. Balanced secondary spermatocyte at metaphase M II, 29Y,t(1,29)) from a $1 / 29$ heterozygous bull. The $\mathrm{Y}$ chromosome and translocation chromosome $(\mathrm{t})$ are indicated. $\times 2300$. 
1
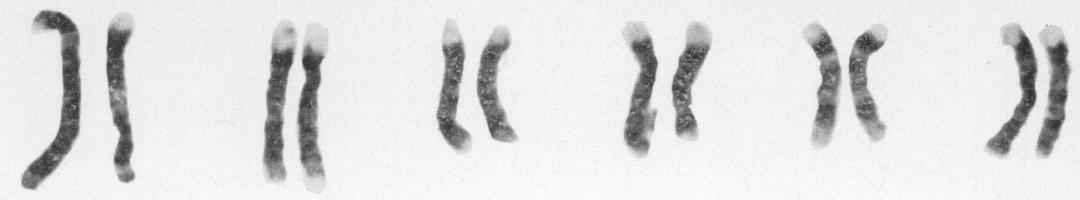

$1+29 ; 1$
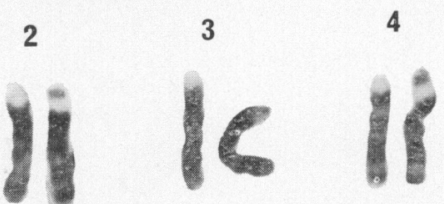

5

6

n

8

9

10

11

12

7

II

i1

II

If

is

13

14

15

16

17

$3)$

88

(1)

II

if

18

19

20

21

22

23

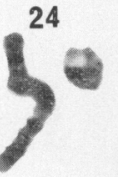

25

26

27

28

29

X Y

2

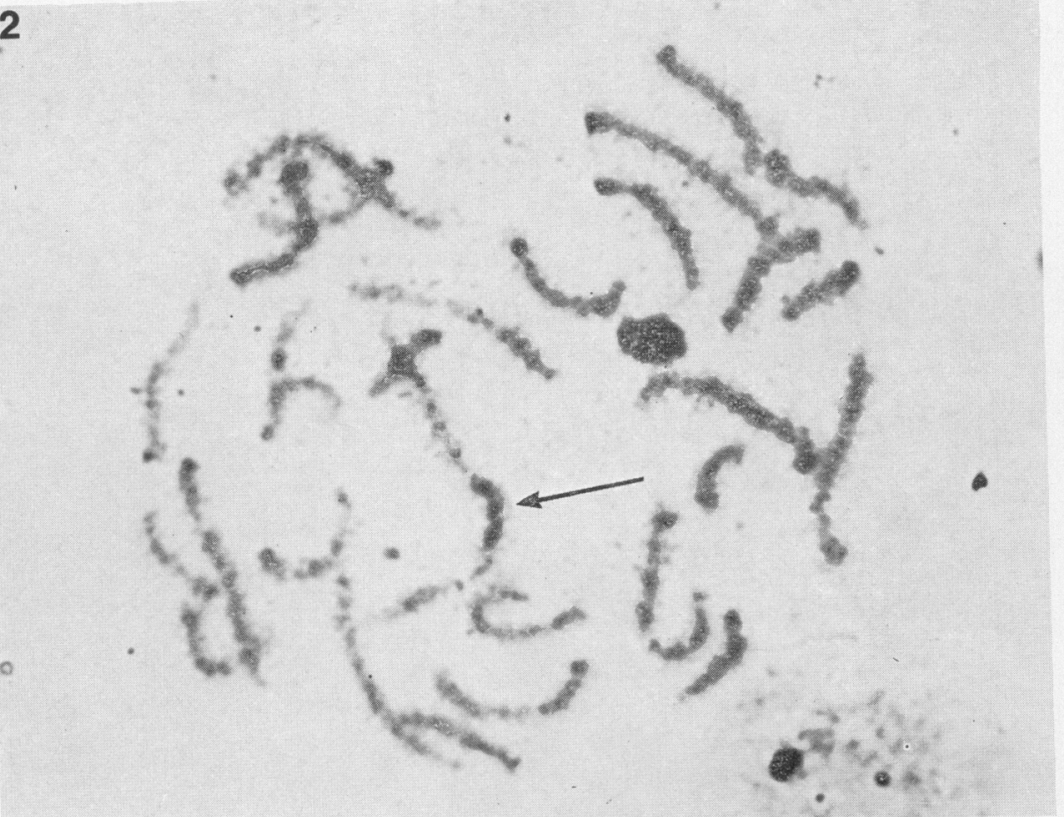




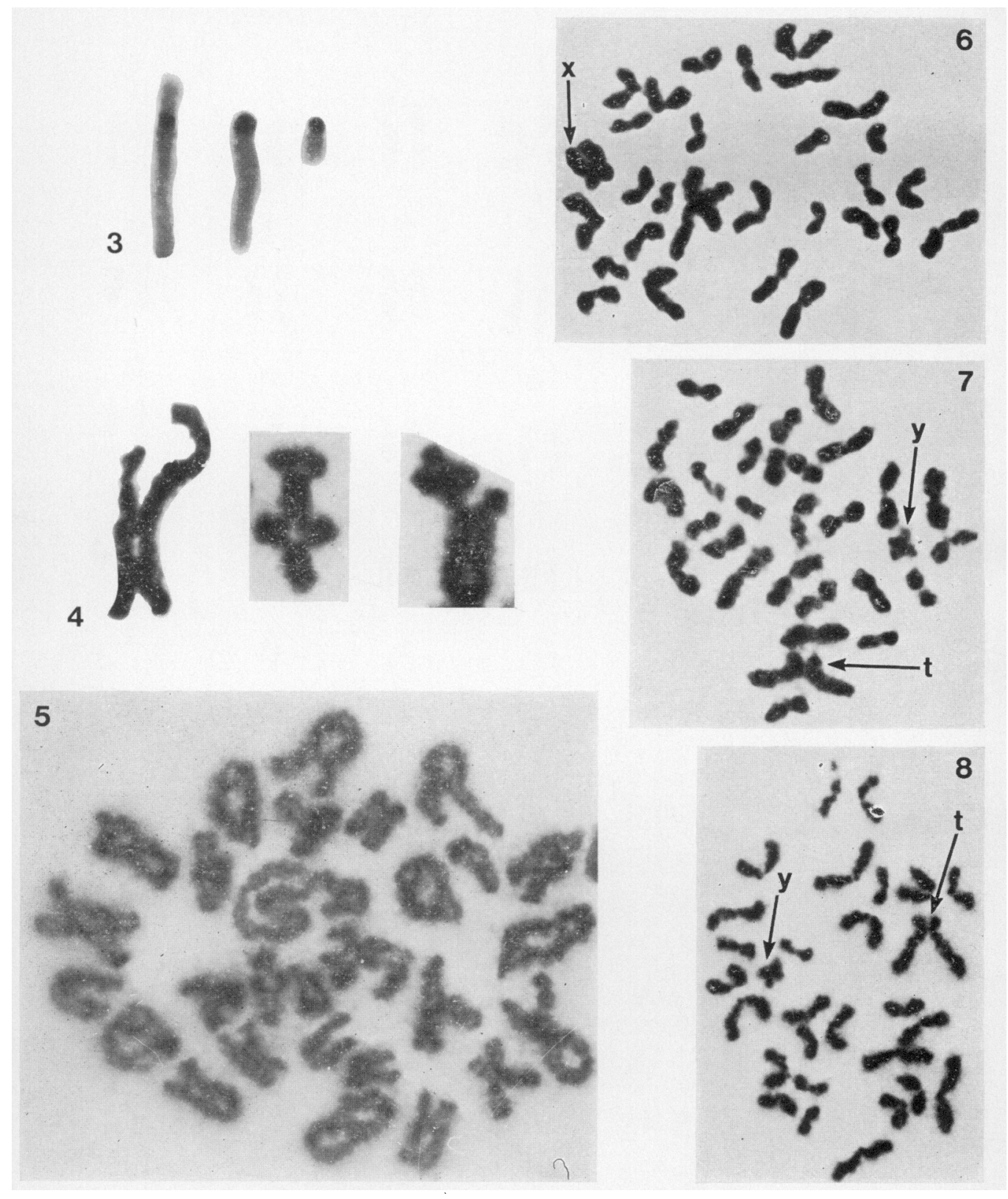


In men and in rams, occasional spermatogenic and testicular abnormalities associated with Robertsonian translocations have been described (Bruère, 1969; Bruère \& Mills, 1971; Chandley et al., 1975). However, in the 3 unselected (i.e. not A.I.) 1/29 bulls of the present study, the service behaviour, semen quality and testicular histology were unimpaired; the Leydig cell volume and relative total tubule length were within the range of 3-30 ml and $1600-3800 \mathrm{~m}$, respectively, found in a slaughterhouse sample of 20 bulls (B. Lennox \& D. Logue, unpublished). These findings confirm the work of Gustavsson $(1969,1975)$, although our numbers of animals were small.

A normal total chiasma count at diakinesis was obtained in the heterozygous bulls. A below average total chiasma count has been reported for men when there was a Robertsonian translocation present (Chandley, Christie, Fletcher, Frackiewics \& Jacobs, 1972), but in their review of human male meiosis, Hultén \& Lindsten (1973) found the majority of cases reported had a normal count. Our simple visual study showed no evidence of an alteration of chiasma position within the two 'component bivalents' of the trivalent. This may have no bearing on the actual points of crossingover, but more refined chiasma studies in man have shown an apparent alteration of positions in the D/D and D/G translocations (Hultén \& Lindsten, 1973). Direct genetic evidence of suppression of crossing over in the proximity of the centromere has been shown to occur in some of the Robertsonian translocations reported in mice (particularly those translocations originating from feral mice), but not in others (Cattanach \& Mosely, 1973), and so it is impossible to generalize at present.

In the study of $M$ II cells, both the $R_{1}$ and $R_{2}$ non-disjunction rates of normal and heterozygous bulls differed significantly, although the $R_{2}$ differences were less clear. Because of the difficulty of distinguishing the separated chromatids from two separate chromosomes, it is felt that these nondisjunction rates are probably over-estimates. Nevertheless, the difference of approximately $5 \%$ non-disjunction between normal and heterozygous bulls in this study compares well with the $4 \cdot 2-$ $5.7 \%$ reduction in fertility noted by Gustavsson (1975) for a series of unselected (i.e. not A.I.) $1 / 29$ heterozygous bulls.

No embryonic studies have yet been made involving the 1/29 translocation in cattle and to date only circumstantial statistical evidence is available to show that the presence of the $1 / 29$ translocation in the Swedish Red and White breed reduces the breeding performance of the female, possibly by a factor as high as 10 percentage points in conception rates (Gustavsson, 1969, 1971a, b; Refsdal, 1976). The present results and information on many other species indicate that these aneuploid cells produced by meiotic non-disjunction form gametes and, subsequently, unbalanced embryos, which then die during early development (Ford, 1975). However, extensive studies of Robertsonian translocation in sheep raises some doubts as to the general applicability of this hypothesis (Bruère, 1976). No detectable deleterious effect on the fertility of carrier male or female sheep has been shown in over 1000 matings, despite the fact that raised levels of non-disjunction have been found in carrier rams (Chapman \& Bruère, 1975; Bruère, 1976). Furthermore, in a study of 102 13-18 day-old embryos, offspring of carrier rams and normal Blackface ewes, no unbalanced chromosome complements of any type were detected (Long, 1976). Chapman \& Bruère (1975) and Long (1976) have proposed that there was a prezygotic selection of spermatozoa, but it is possible that the gametic products of nondisjunction events formed unbalanced embryos and that these died in the first 12 days of life and were amongst the relatively large proportion (25\%) which Long (1976) could not karyotype. This value of $25 \%$ is remarkably close to the expected early embryonic loss in sheep, although this can vary from 9 to $64 \%$ in Blackface ewes kept on different feeding regimens (Gunn \& Doney, 1975). This large variation in early embryonic loss could explain the observed, apparently normal, fertility of heterozygous sheep for which the theoretical anticipated reduction of fertility may be quite small.

The present results give theoretical support to the evidence that there is some reduced fertility in $1 / 29$ heterozygous cattle (Gustavsson, 1969). It would, however, be quite a small loss, e.g. requiring one extra insemination in approximately 20 inseminations to ensure pregnancy in a heterozygous cow. This is not an immense load for an individual herd, especially if the carrier animals have other redeeming genetic or phenotypic qualities. On the other hand there may be no advantage and the rather small negative selection pressure could be over-ridden by random genetic drift, an hypothesis favourably considered in a more general context by some population geneticists (Kimura, 1976). 
Until more information is available, it seems prudent to limit the widespread use of translocation carrier bulls as A.I. sires, while maintaining the translocations on a herd basis for further study. Study of the chromosome complements of the first cleavage mitosis after in-vitro fertilization, as in the mouse (Maudlin \& Fraser, 1977), would be of great value as it would provide a cheap and efficient method for determining the possible fates of aneuploid secondary spermatocytes and oocytes.

We thank Dr C. E. Ford for his most helpful advice, encouragement and criticism; Professor M. A. Ferguson-Smith, Professor A. N. Bruère, Professor B. Lennox and Mr P. G. Hignett for advice; Mr D. Eyon for technical assistance; and Mrs Pamela Dean for typing the manuscript. The work was supported by the Agricultural Research Council and the Wellcome Trust.

\section{References}

Ahmad, K.N., Dykes, J.R.W., Ferguson-Smith, M.A., LENNOX, B. \& MACK, W.S. (1971) Leydig cell volume in chromatin positive Kleinfelter's syndrome. $J$. clin. Endocr. Metab. 33, 517-526.

BASRUR, P.K. \& Gilman, J.P.W. (1964) A blood culture method for the study of bovine chromosomes. Nature, Lond. 204, 1335-1337.

BASRUR, P.K., BASRUR, V.R. \& Gilman, J.P.W. (1963) A simple method for short-term cultures from small biopsies. Expl Cell Res. 30, 229-232.

Bruère, A.N. (1969) Male sterility and an autosomal translocation in Romney sheep. Cytogenetics 8, 209218.

BrUère, A.N. (1974) The discovery and biological consequences of some important chromosome abnormalities in domestic cattle Proc. 1st Wld Congr. Genetics applied to Livestock Production, Madrid, pp. 151-175. Editorial Garci, Graficas Orbe., Madrid.

BRUÈRe, A.N. (1976) Origin and significance of centric fusions in domestic sheep. J. Hered. 67, 149-154.

BRUÈRE, A.N. \& Mills, R.A. (1971) Observations on the incidence of Robertsonian translocations and associated testicular changes in a flock of New Zealand Romney Sheep. Cytogenetics 10, 260-272.

Cattanach, B.M. \& Moseley, H. (1973) Non-disjunction and reduced fertility caused by the tobacco mouse metacentric chromosomes. Cytogenet. Cell Genet. 12, 264-287.

Chandley, A.C., Christie, S., Fletcher, J., Frackiewicz, A. \& JacoBs, P.A. (1972) Translocation heterozygosity and associated subfertility in man. Cytogenetics 11, 516-533.

Chandley, A.C., Edmond, P., Christie, S., Gowans, L., Fletcher, J., Frackiewicz, A. \& Newton, M. (1975) Cytogenetics and infertility in man I. Karyotype and seminal analysis. Ann. hum. Genet. 39, 231252.

Chapman, H.M. \& BruÈre, A.N. (1975) The frequency of aneuploidy in the secondary spermatocytes of normal and Robertsonian translocation-carrying rams. J. Reprod. Fert. 45, 333-342.

Eldridge, F.E. (1974) A dicentric Robertsonian translocation in a Dexter cow. J. Hered. 65, 353355.

Ferguson-SMITH, M.A. (1964) The sites of nucleolus formation in human pachytene chromosomes. Cytogenetics 3, 124-134.
Ferguson-Smith, M.A. (1971) Human chromosomes in meiosis. Proc. 4th Int. Congr. Human. Genetics, Paris, pp. 195-211. Eds J. de Grouchy, F. J. G. Ebling \& I. W. Henderson. Excerpta Medica, Amsterdam.

Ford, C.E. (1975) The time in development at which gross genome inbalance is expressed. In The Early Development of Mammals, pp. 285-304. Eds M. Balls \& A. E. Wild. Cambridge University Press.

FoRD, C.E. \& EvaNs, E.P. (1973) Robertsonian translocations in mice: segregational irregularities in male heterozygotes and zygote imbalance. In Chromosomes Today, Vol. 4, pp. 387-397. Eds J. Warhrman \& K. R. Lewis. Wiley \& Sons, New York.

GunN, R.G. \& DoneY, J.M. (1975) The interaction of nutrition and body condition at mating and ovulation rate and early embryo mortality in Scottish Blackface ewes. J. agric. Sci. Camb. 85, 465-470.

Gustavsson, I. (1969) Cytogenetics distribution and phenotypic effects of a translocation in Swedish cattle. Hereditas 63, 68-169.

Gustavsson, I. (1971a) Culling rates in daughters of sires with a translocation of centric fusion type. Hereditas 67, 65-74.

Gustavsson, I. (1971b) Chromosomes of repeat breeder heifers. Hereditas 68, 331-332.

Gustavsson, I. (1974) Appearance and persistence of the $1 / 29$ translocation in cattle. In Les Accidents de la Reproduction, pp. 147-153. Eds A. Boué \& C. Thibault. Louis-Jean, Paris.

Gustavsson, I. (1975) New information on the reduced fertility of cattle with the 1/29 translocation. Proc. 2nd Eur. Colloq. Cytogenetics in Domestic Animals, pp. 184-188. Giessen University.

Gustavsson, I., \& Rockborn, G. (1964) Chromosome abnormality in 3 cases of lymphatic leukaemia in cattle. Nature, Lond. 203, 990.

HARVEY, M.J.A. (1971) An autosomal translocation in the Charolais breed of cattle. Vet. Rec. 89, 110-111.

HignetT, P.G. (1957) The general examination of the bull for soundness with special reference to the assessment of fertility. Vet. Rec. 69, 1140-1146.

Hultén, M. \& LinSDTEN, J. (1973) Cytogenetic aspects of human male meiosis. In Advances in Human Genetics, Vol. 4, pp. 327-387. Eds H. Harris \& K. Hirschorn. Plenum Press, New York. 
Kimura, M. (1976) How genes evolve: a population geneticists view. Annls Génét. 19, 153-168.

Lennox, B., AHMAD, K.N. \& MACK, W.S. (1970) A method for determining the relative total length of the tubules in the testis. J. Path. 102, 229-238.

LoGuE, D.N. (1975) A study of bovine cytogenetics. Ph.D. thesis, University of Glasgow.

LONG, S.E. (1976) An investigation of a centric fusion (Robertsonian) translocation of sheep. Ph.D. thesis, University of Glasgow.

MAudlin, I. \& Fraser, L.R. (1977) The effect of PSMG dose on the incidence of chromosomal anomalies in mouse embryos fertilized in vitro. $J$. Reprod. Fert. 50, 275-280.
Pollock, D. \& Bowman, J.C. (1974) A Robertsonian translocation in British Friesian cattle. J. Reprod. Fert. 40, 423-433.

POPEsCu, C.P. (1973) L'hétérochromatin constitutive dans le caryotype bovine normal et anormal. Annls Génét. 16, 183-188.

REFSDAL, A.O. (1976) Low fertility in daughters with a 1/29 translocation. Acta vet. scand. 17, 190-195.

SEABRIGHT, M. (1971) A rapid banding technique for human chromosomes. Lancet ii, 971-972.

SumNer, A.T. (1972) A simple technique for demonstrating centromeric heterochromatin. Expl Cell Res. 75, 304-306.

Received 3 February 1978 